\title{
CLAH LECTURE: Learning and Teaching
}

\begin{abstract}
The following speech was written in acceptance of the Distinguished Service Award of the Conference on Latin American History (CLAH) for 2020, would have been delivered at the January 2021 meeting of the American Historical Association/CLAH, were it not for the coronavirus pandemic. I share this award with the majority of the members of CLAH: the scholar-teachers of Latin American history who dedicate most of their professional time and energy to teaching undergraduates across North America. Harking back to Herbert Bolton's project for a hemispheric history, incidents and anecdotes from my own experience learning and teaching about Latin America serve to illustrate that reducing provincialism, chauvinism, and ethnocentrism among North American undergraduates are still valid objectives.
\end{abstract}

KEYWORDS: teaching, research, Latin America

$\mathrm{I}$

want to express my profound gratitude to the review committee and my CLAH colleagues for this singular honor. I also want to share this award with that majority of CLAH members who dedicate their expertise and the bulk of their professional time and energy to teaching and mentoring undergraduate students in colleges and universities across North America, the scholar-teachers of Latin American History.

I'll begin with a leading question: Why are we here? No, I'm not wondering why human beings exist. Nor am I asking why a small subset of the CLAH membership has just had lunch with old friends and new acquaintances, after which prizes are announced. My question is why an organized group of a thousand or so academic specialists in the history of Latin America - one of the largest of the many affiliated societies of the American Historical Association-exists. Circumstances prevent us from engaging in a Socratic exchange, so please bear with me.

Are we here to do research? Carrying out a major research project is the appropriate credential for university-level teaching, and ongoing research is the expectable norm for moving up through the professorial ranks. All CLAH members, or nearly all, have done research somewhere in Latin America, most have published results from those experiences and they continue to do so as opportunity and resources permit. It's how we learn new things, and develop new ways of understanding old things. In research and writing we develop skills that we then pass on to students at all levels. Engagement with networks 
of mentors and colleagues in the areas where our research takes place is an essential element of such activity. As is the case with many academic organizations, the array of CLAH prizes and awards privileges research over teaching, and logically so. How could such an organization possibly evaluate the teaching of those with whom I share this award?

But as I have suggested, the majority of CLAH members spend most of their time, and most of their careers, teaching undergraduates, in English, in North American institutions of higher education. The simple and obvious reason for this situation is that we think it is important for Latin American history to be taught to English-speaking North American students. We fulfill the symbolism of the CLAH logo, which portrays not just Latin America or North America, but the entire Western Hemisphere.

And how do we develop the expertise that we bring to bear in carrying out that teaching mission? We learn it, in both formal and informal ways. Some of my own students (and colleagues, I might add) have responded with a raised eyebrow or rolled eye when I say that history is imaginary-that it exists only as a figment of our imagination. I respond to such skepticism by asking where history exists, outside of our minds. None of the ink on paper, material objects, or in more recent times pixels on screens becomes history until we put such elements together in our own minds. ${ }^{1}$ They become part of our experience. One way to illustrate my own relationship to Latin America and its history is to share a not-quite-random smattering of my own formal and informal learning experiences, and their relationship to teaching.

My first course in Latin American history, in 1965-66 at the University of California Santa Barbara, was "History of the Americas," taught by Lawrence Kinnaird. It mostly involved descriptive narration from the podium and regurgitation on exams, but I got the basic outline and major themes, as those had been defined in the first half of the twentieth century. Kinnaird received his $\mathrm{PhD}$ at UC Berkeley in 1928, under the direction of Herbert Eugene Bolton. I think that makes me just two degrees removed from one of the foundational figures of Latin American history in the United States, the person for whom the CLAH Bolton-Johnson best book award was originally named (Johnson's name was added in 2000). The textbook for the course was History of the Americas in two 600-page hardbound volumes, by John Francis Bannon, S.J., another Bolton $\mathrm{PhD}^{2}$ I mention this not to impress you with a trivial bit of

1. As Carl Becker noted in a paper first delivered at the AHA in 1926, "The historical fact is in someone's mind or it is nowhere." Published as "What Are Historical Facts?" Western Political Quarterly 8:3 (September 1955): 331.

2. John Francis Bannon, History of the Americas, 2 vols. (New York: McGraw-Hill, 1963). 
my professional trajectory, and how long ago it began, but to remind us of Bolton's vain hope, stated most forcefully in his 1932 presidential address to the AHA, that American history could become worthy of that label by embracing "The Epic of Greater America"-as he titled his speech, which fittingly was delivered at the first AHA meeting held outside the USA, in Toronto. $^{3}$

Today Bolton is appropriately recognized for his focus on the Spanish borderlands in North America, but his AHA address laid out a much broader project-a hemispheric history. ${ }^{4}$ It is an interesting read even today, if you can get past some of the groan-inducing antiquated, not to say archaic, imagery. He said, for example, that the Native groups in Spanish America "were easiest to conquer, were most worth exploiting, and their women made the best cooks." Speaking after some three decades of imperial expansion and neocolonialism by the United States, including direct military intervention and occupation, Bolton characterized those developments in the most euphemistic language imaginable: "In recent years the United States has had its most intimate relations with the Isthmus and the Caribbean area. In these regions the United States has exercised extensive supervisory functions.”

He unselfconsciously referred to the United States and the antecedent colonies as "Saxon America," even as he chastised his fellow United Statians for their arrogantly narrow perspective: "In Saxon America the story of the 'struggle for the continent' has usually been told as though it all happened north of the Gulf of Mexico. But this is just another provincialism of ours." And another Bolton comment, one we can still identify with: "In my own country the study of thirteen English colonies and the United States in isolation has obscured many of the larger factors in their development, and helped to raise up a nation of chauvinists." To his everlasting credit, Bolton, a self-identified denizen of "Saxon America," believed that to help break through that provincialism and chauvinism, the study and teaching of Latin American history would be salutary.

I spent 1966-67, during that too-brief interval between La Violencia and the drug wars, in a full immersion study-abroad program at the Universidad de los Andes in Bogotá, Colombia. On an excursion to see the salt cathedral of Zipaquirá, several of us were slaking our thirst at a snack bar when workers who had just finished their shift in the still-functioning salt mine filed by, in battered fedoras and blanket-like ruanas. A shiny car with darkened windows

3. Herbert Eugene Bolton, "The Epic of Greater America," American Historical Review 38:2 (April 1933): 44874 , also available on the AHA website.

4. It is not my intention to discuss the general question, which was done well in Lewis Hanke, ed., Do the Americas Have a Common History? A Critique of the Bolton Theory (New York: Knopf, 1964), available in the Internet Archive. 
approached, and as it passed the workers removed their hats and bowed. I grew up on cattle ranches and pack stations in the Great Basin of the United States, where no employee would remove his hat in deference to the boss, much less bow his head. Seeing those miners bow to the boss's car, hat in hand, had a profound effect on me.

Later, on a bus trip to see the Semana Santa celebrations in Popayán, I saw scattered cattle grazing on latifundia in the fertile flatlands of the Cauca Valley, while families grew food crops on minifundia plots clinging tightly to surrounding hillsides. That's backwards, I thought. The cattle should be grazing in the hills, and the flatlands should be used in more productive ways. I wondered how such a situation had come about. At Los Andes I learned a lot from courses in history, anthropology, political science, and economics, but my own observations and reflections outside the classroom made the year in Colombia an intense experience.

Back in Santa Barbara, I took a course on inter-American relations from Donald Dozer. Student lore had it that Dozer had been pushed out of his position in the State Department during the era of John Foster Dulles, for being too conservative. One point he tried to drive home was that land reform, as promoted under the Alliance for Progress, was theft. After my epiphany in the Cauca Valley, I had been reading up on the agrarian history of Latin America. In an essay on the final exam in Dozer's class I tried to make the case that breaking up neo-feudal estates, making more rational use of land, and improving the condition of country people through agrarian reform, were good things. It can now be revealed that one of the two "C" grades on my undergraduate transcript was in an upper-division course on inter-American relations. (The other was in Introduction to Philosophy, another story.)

Starting graduate school at the University of Wisconsin-Madison in 1968, I signed up for a seminar with John Leddy Phelan. He had just completed The Kingdom of Quito in the Seventeenth Century: Bureaucratic Politics in the Spanish Empire, and the seminar was to focus on the administrative structures of the Spanish colonies. ${ }^{5}$ On Day 1, Phelan informed us that in preparation for the material we were going to read what I understood as "Mocks VEY-bear." I had never heard of Max Weber. That soon changed, in that class and in seminars with Peter Smith. I came to appreciate interpretation based on the probabilistic relationships among political, economic, and social factors, and that much

5. John Leddy Phelan, The Kingdom of Quito in the Seventeenth Century: Bureaucratic Politics in the Spanish Empire (Madison: University of Wisconsin Press, 1967). 
historical analysis measured observed phenomena against Ideal-type paradigms, even when the paradigms were not made explicit.

Peter Smith was entering his extreme Carl Rogers phase, and my cohort later got a shock when at the first meeting of a graduate seminar, instead of handing out a syllabus, he asked us what we wanted to study. Imagine that. After spinning our wheels for a couple of weeks, we finished the semester with one of the most rewarding experiences of my time in Madison. I never tried anything so daring, but I did work to incorporate concepts and techniques of student-centered learning in my teaching, to good effect I think.

From Thomas Skidmore I learned to read everything you could find on a topic before you write about it. As his research assistant on the project that became Black into White: Race and Nationality in Brazilian Thought, I spent many hours hunched over a microfilm reader browsing newspapers from the early twentieth century, scanning for commentary on racial matters. ${ }^{6}$ My distracted eye began to catch recurring references to the overproduction of coffee in São Paulo, culminating in a disastrously large crop in 1906, which in turn led to the first major commodity price support scheme in the modern era, called valorization. That gave me a topic for a Master's thesis, and eventually a first book. $^{7}$

But there was more. The contemporary reports claimed that a major reason planters opened new groves was because the immigrant workers who had replaced slaves in the coffee labor force after 1888 wanted to grow food crops among the immature coffee shrubs, and that as the coffee matured, new groves had to be opened to attract workers. The notion that plantation laborers could pressure estate owners to take action favoring the workers, eventually resulting in overproduction and lower coffee prices, contrary to the interests of the planters, ran counter to common assumptions about plantation labor regimes. This would be agency avant la lettre. I abandoned my plan to study the agrarian history of the Cauca Valley, and headed for São Paulo.

Long story short, after a year of research I was ready to rate the claim as mostly true. Not only was pressure from colonos a factor leading to overproduction of coffee, but there was convincing evidence that a significant number of immigrants were able to save enough as plantation laborers to buy land and become independent smallholder coffee farmers themselves. Rather than

6. Thomas Skidmore, Black into White: Race and Nationality in Brazilian Thought (New York: Oxford University Press, 1974).

7. Thomas H. Holloway, The Brazilian Coffee Valorization of 1906: Regional Politics and Economic Dependence (Madison: State Historical Society, 1975). 
making a priori assumptions about the workers' fate, I learned what the sources taught and allowed myself to be surprised. ${ }^{8}$

I took a full time job in 1974, and spent the next 17 years as the only Latin Americanist in a History department of more than 30 full-time faculty. With little prospect of developing a viable and competitive graduate program in my field, I focused on undergraduate teaching, with the attendant frustrations and rewards. At a time when teaching materials tended toward ponderous textbooks, I came to appreciate the efforts of some senior scholars in making translated documents and interpretive essays accessible to the expanding audience of English-only undergraduates. Particularly prominent in this regard was the work of Professor Lewis Hanke, the namesake of another CLAH prize, who in the 1960s and 1970s served as the general editor of the 30 volumes of Knopf's Borzoi books on Latin America, and published several other volumes of issue-focused readings. ${ }^{9}$

I sought inspiration in the work of such figures as Carl Rogers. ${ }^{10}$ Also inspiring were Carl Becker (whose presidential address to the AHA in 1931, in the year immediately preceding Bolton's, was entitled "Everyman His Own Historian"), and Paulo Freire. ${ }^{11}$ Inspiration was one thing, but guidance and implementation quite another. I tried to decenter (again, avant la lettre) the role of the instructor, becoming to the extent possible a facilitator, taking to heart the meaning of "pedagogue" in Ancient Greece-the servant who leads the young person to the place of learning. I understood the expectations of my profession, my students, and my employer, and carried out my own role as a source of information, analysis, and interpretation, but no more authoritative a source than any other-including the interpretation and analysis students brought to bear from their own experience, which included their own reading and research, and working together outside of my supervision. I was not always successful, and I'm sure many scholar-teachers of Latin American history and many other fields have done better than I did, but the response from students was gratifying, and I will never regret the time and effort I put into it.

8. Thomas H. Holloway, Immigrants on the Land: Coffee and Society in São Paulo, 1886-1934 (Chapel Hill: University of North Carolina Press, 1980).

9. See "The Writings of Lewis Hanke," Inter-American Review of Bibliography 36:4 (1986): 427-451; and Lewis Hanke, David Bushnell, and Lyle McAlister, "An Interview with Lewis Hanke," Hispanic American Historical Review 68:4 (November 1988): 653-674.

10. The literature is voluminous. An entry point is Carl Rogers, Freedom to Learn: A View of What Education Might Become (Columbus, OH: Charles Merrill, 1969). A problem I had with Rogers's Zen-like aphorisms was fleshing them out with concrete subject matter, so purists might call my efforts 'Rogers light,' or 'Rogers watered-down.'

11. Carl L. Becker, "Everyman His Own Historian," American Historical Review 37:2 (January 1932): 221-236, also available on the AHA website. See also his "What Are Historical Facts," Western Political Quarterly 8:3 (September 1955): 327-40. Paulo Freire's best-known work is Pedagogy of the Oppressed (New York: Continuum, 1970). See also his Education for Critical Consciousness (New York: Seabury, 1973). 
These days, when students have access to an immense trove of historical facts and interpretation of them via an electronic device in their hand or backpack, I would find no excuse for creating an experience similar to the one I had with Lawrence Kinnaird in 1965. But neither is there an excuse for my experience with Donald Dozer, with his declaration that land reform was theft. That was confirmed for me in 1997 when, as a member of the faculty team on a study trip to Ecuador, I met an elderly gentleman at a community center high in the Andes, near the Colombian border. The students were partying inside with their Ecuadorian counterparts, so he and I had moved out to the veranda for some calm. As we looked out over the broad hillsides dotted with potato fields, pastures, and dairies, I asked him where he lived. "Over there, all my life," he pointed to a farm with whitewashed house, animal sheds, and a building where his family made cheese for sale in regional markets. He went on to tell me that he had spent the first half of his long life in a community of huasipungueros, tenants who paid rent to the bacendado in labor, in return for permission to live in a hut on a small plot where they were allowed to grow their own food. ${ }^{12}$ The plots where they lived, their rental contracts, and thus the people bound by those contracts, were the property of the hacienda, bought and sold like land or livestock.

Their condition would have been familiar to the serfs of Europe a thousand years ago. He and his neighbors had been freed from serfdom by the land reform law of 1964, not long before my encounter with Professor Dozer. Like my passing observation of the deferential Zipaquirá salt miners in 1966, that conversation in highland Ecuador in 1997 was a moving experience, made the more so by my experiences in learning and teaching the history of Latin America in the intervening decades.

Herbert Bolton taught his immensely popular course at UC Berkeley from 1919 to 1944. As he said upon receiving The Americas award for 1949: "For a quarter century I lectured to more than a thousand students twice a week."13 Most of us can only imagine what that might have been like, but I would like to think he succeeded in helping to reduce or ward off provincialism and chauvinism in his legions of undergraduates. I don't think CLAH membership records go back that far, but I would be surprised to learn that as of 1950 there were more than 50 full-time post-secondary instructors of Latin American history in North America. That situation has changed, with the most dramatic expansion taking place around the time I took Bolton's course from one of his followers. I'm

12. Their situation is the context for a classic of Latin American indigenist and social realist literature. Jorge Icaza, Huasipungo (Lima: Mejia Baca \& Villanueva, 1934).

13. Herbert Eugene Bolton, "The Confessions of a Wayward Professor," The Americas 6:3 (January 1950): 362. 
pleased to think that I have had a small part in mitigating any tendency to provincialism and chauvinism, to which I would add ethnocentrism and a few other negative -isms, in students whose paths have crossed mine. I share the CLAH Distinguished Service Award with the scholar-teachers of Latin American history who continue their own versions of that project, now and into the future. It's why we are here.

University of California Davis

THOMAS HOLLOWAY

Davis, California

thholloway@ucdawis.edu 